\title{
Inter et Inter: A Report on the Metamorphosis of an Actress
}

\author{
ISOBEL BOWDITCH
}

I.

In 1847, Johanne Luise Heiberg, a Danish actress and friend of Søren Kierkegaard, performed the role of Juliet in Shakespeare's Romeo and Juliet in the Copenhagen theatre. This occasion prompted Kierkegaard to write an article for the newspaper Fadrelandet, called "The Crisis and a Crisis in the Life of an Actress" under the curious name of Inter et Inter. This would hardly be a notable event except for the fact that Kierkegaard had only just publicly resolved to cease his literary activity once and for all and instead to write under his own name as a religious author.

Kierkegaard frequently refers almost dismissively to "The Crisis and a Crisis in the Life of an Actress" as the "little article." Despite this and the fact that it has had little attention in Kierkegaard scholarship, its publication appeared to represent a significant risk for him, both personally and professionally. At the time, Kierkegaard was still reeling from "The Corsair Affair." Two years earlier, Peder Ludvig Møller had written a negative review of Kierkegaard's Stages on Life's Way, which Kierkegaard felt to be both unfair and ill-conceived. Møller was also a contributor to The Corsair, a Danish satirical newspaper which lampooned public figures. Kierkegaard, who until this point had been well regarded by the editor of The Corsair, wrote two responses to Møller's review for publication in the newspaper, vehemently attacking not only The Corsair itself but openly inviting the editor to satirize him. Kierkegaard successfully 
discredited Møller but the deeply personal and sustained assault which followed in the same newspaper exceeded anything he anticipated. As a result, Kierkegaard, a very well-known figure on the streets of Copenhagen was ridiculed wherever he went. Kierkegaard was aware that this painful experience would be interpreted as the reason he decided to give up his literary authorship. However, his journal entries state that he was doing so of his own free will, not because he was being forced to by anyone else. In Concluding Unscientific Postscript to Philosophical Fragments, completed before the "The Corsair Affair" and published in 1846, he had already listed all of his pseudonymous creations, claimed them overtly as his own creations and took his leave of them. Whatever the reason, the fact remained that he had publicly resolved to relinquish his pseudonymous authorship. To then publish an article about an actress under the name Inter et Inter in a popular newspaper was a compromising decision for Kierkegaard.

II.

When Frau Heiberg took the role of Juliet in 1847, she was 30 years of age. She had only played Juliet before at the age of 16 in a performance that had wooed the theatre-going public of Copenhagen, helping to establish her reputation as a leading actress and prominent figure on the Danish cultural scene of the time.

The subject of "Crisis" is simply referred to as "the actress." It was not until three years after its publication that Kierkegaard revealed to Frau Heiberg that the actress to whom he had referred was indeed her. Why was this event of consequence to Kierkegaard and why did the decision to publish this "little article," which he discusses at length in his journals, cause him so much anguish $?^{2}$ 
At this time, Kierkegaard felt that the significance of the individual was being undermined by ideological forces taking root in Denmark. The political climate was of collective rather than individual struggle (it was in 1848 that Marx and Engels wrote The Communist Manifesto, for example) and in Christianity the people's church was thriving as a collective means of worship. For Kierkegaard, the "single individual" was key to both spiritual development and to his emphasis on existential truth as subjectively appropriated. The mentality of the crowd turned itself to external concerns, whereas the individual (before God) sought an inner transformation which had no recognisable value in worldly terms: "Earthly reward, power, honour, etc are not bound up with its proper use...-inwardness is of no interest to the world..." (Papers 351).

As someone aspiring to the Christian life, Kierkegaard valued the silent and unrepresentable character of "inwardness," but as a philosopher he wanted "to speak." His indirect authorial strategy was a way of speaking without speaking. ${ }^{4}$ It delivers interpretative responsibility over to the reader but also brings us into a productive relation with what Kierkegaard called "the universal" (Papers 372$).{ }^{5}$ The notion of "the single individual" pitted against the collective may suggest solipsism but for Kierkegaard, the mentality of the crowd not only encouraged an avoidance of personal responsibility but was the severest kind of selfdeception; it denied the reality, difficulty, contradictions and indeed the full span of experience that is human existence, quelling difference and dissent:

The sparrows rightly peck to death the sparrow which is not like the others, for here the species is higher than the specimens, i.e. sparrows are animals, no more, no less. In respect of what characterizes the human, each is meant on the contrary not to be like the others, to have its peculiarity.

Yet human beings forgive every crime except for that of being what in their view is to be unhuman-namely to be a human being. (Papers 311) 
The single individual is more than an ideal, he says; it is a "category of awakening when things are complacent and of 'conciliation' when things are tottering" (Papers 351). Unlike singular existence, the category of the universal does not allow subjectivity to be lived in its full potential, that is, as paradox. The comparison is exemplified in Concluding Unscientific Postscript where, under the pseudonym Johannes Climacus, Kierkegaard says that it is possible to reach a conclusion about the existence of God, both through objective reason and subjective experience. However, he asks, "on which side is truth?” If we could attain purely objective truth then we would cease to be human, becoming instead some "fantastical somebody" (Postscript 220). Essential truth for Kierkegaard is related to subjective existence or inwardness, and as such is paradoxical, that is as a collision between subjective experience and objective knowledge. ${ }^{6}$ Although existence seems to oscillate between subject and object, Kierkegaard suggests that it may be possible to break out of this flux in a moment of passion:

[T]o exist is to become. An existing person cannot be in two places at the same time, cannot be subject-object. When he is closest to being in two places at the same time, he is in passion; but passion is only momentary, and passion is the highest pitch of subjectivity. (Postscript 199)

It is possible momentarily for an individual to inhabit this impossible ground through passion: "for the existing person, passion is existence at its very highest-and we are, after all, existing persons... in passion, the existing subject is infinitized in the eternity of imagination and yet is also most definitely himself" (Postscript 196 -197). The word "passion" from the Greek pathos (literally, "what befalls one") and the Latin passio meaning "suffering" or "being acted upon" (from the Latin verb pati, to suffer) also means "devotion" or "enthusiasm." The Latin root of "to suffer" is sufferre, from sub (up) + ferre (to bear) meaning to submit, to endure, to feel or to undergo. Passion then, linked to the idea of suffering, is not (or not only) a helpless or 
pitiful state but something bestowed upon me and voluntarily borne and lived by me. For Kierkegaard, "esthetic pathos" whereby an individual "abandons himself in order to lose himself in the idea" is distinguished from "existential pathos" which "results from the transforming relation of the idea to the individual's existence." The latter is not an intellectual move, a change of mind, but rather a response to "the tug of decision that changes everything" (Postscript 387388). As Kierkegaard points out, the word "passive" in Danish is the same as the word "affect," which is more likely to evoke "the convulsive boldness which astounds us, and because of that we forget that it is suffering" (Fragments 49). Passion, then, is also to be affected in such a way that the individual seems to have willingly taken it upon themselves to suffer.

What Kierkegaard calls the psychological, or "the imaginative constructing" that comes about in "man in concreto," is the embodiment of the paradox, in other words the truth of existence. ${ }^{7}$ The paradox, which emerges from "the placing together of the eternal and existing human being," could not be embodied and lived in full without subjectivity. Without the existing human being, truth would remain forever outside, like a phantom, unable to take form. The existing individual is also the "learner," the one who is oblivious to the truth and therefore in "un-truth" (or sin). A learner is capable of passion, being acted upon in such a way that they are willing to be changed. To come into existence as existent, as the single individual, is to suffer existence in all its paradoxical glory. Looked at it from this point of view, passion as suffering is very far from being a state of subjection in an impotent sense, but is rather a state in which I deliver myself wholeheartedly to existence.

If the threat to the "single individual" was as forceful in 1847 Copenhagen as Kierkegaard feared, there may have been reason for him to take up indirect communication once more in order to counter its increasing influence. However, what was it about the seemingly 
unprepossessing situation of Frau Heiberg's performance as Juliet that precipitated this turnaround? Like Fear and Trembling, the great "dialectical lyric" on Abraham, "Crisis" uses the example of an individual in a particular situation. Unlike Abraham, Frau Heiberg is a recent historical figure known personally to Kierkegaard. However exceptional an actress she was, her achievements may not inspire awe in the same way as those of Abraham, the father of faith, called by God to sacrifice his own son. She simply had a job as an actress. On first view, "Crisis" offers little clue. There is no evident life or death dilemma, no heroic act on the part of the actress and, at first, it is not at all clear to what event the "crisis" of the title refers.

\section{III.}

Kierkegaard's polyphonic method projects into the world a series of disparate and elusive characters whose viewpoints could be quite different from those held by Kierkegaard himself (one is never quite sure). Indeed, he often claimed that they were alien to him, as though they really were other people. ${ }^{8}$ Two characters circulate on the periphery of "Crisis," and, even before we start to read the text, we are confronted by a curious deflection from the representation of a tangible subjective agency. One is the author, Inter et Inter, and the other is Juliet.

Even by Kierkegaard's standards, the pseudonymous author of "Crisis" is enigmatic. It is difficult to imagine to what human form the name "Inter et Inter" may belong. The term Inter is Latin for the preposition "between." Grammatically speaking, prepositions are linking words, relating words or phrases to each other. "Between" describes a link which is also a separation or division. Inter et Inter, "between and between," is a nonsensical adjunct of two prepositions, linked to nothing but themselves and posing as a noun or a name. ${ }^{9}$ If anything, Inter et Inter is suggestive of a period of time or movement rather than a person. Yet, in another sense, it is a 
pseudonym par excellence. This "little article," both as an anomaly in a sequence of religious works and authored by this incognito Inter et Inter, signals a work of ambivalent status in the body of Kierkegaard's writing. Such ambivalence serves to intensify the dialectic at work in his indirect authorship.

The character of Juliet, we know, was written by Shakespeare to represent a thirteen yearold girl ("not quite fourteen"). Juliet's vocabulary is perhaps better suited to a woman of thirty than a thirteen year-old child and it is common to find an older actress playing the part. Yet Romeo and Juliet is also a tale of first love, of youthful idealism, an antidote to the worldly concerns represented by the protagonists' families. Add to this the fact that in Shakespeare's original company there were no women actors so that young men played female characters, the role of Juliet itself, both in its artistic content and its theatrical history, starts to set up a web of elliptical subjects. As such it is a demanding role for an actress at any time. The actress in "Crisis" would have understood this much, at least, in taking on the role of Juliet.

However, it is not the story of Shakespeare's star-crossed lovers in Romeo and Juliet, that seems to be of concern to Kierkegaard, but rather what he calls the "metamorphosis" of the actress, something he says that was not only difficult, but also "beautiful and significant" ("Crisis" 199). Metamorphosis is a transformation in stages, a process involving substitution rather than evolution. A butterfly is in no way essentially the same as the chrysalis from which it was formed. Yet the question of how it is possible for an entity to change without retaining some continuity has been a subject for philosophers since Artistotle. Aristotle suggests the notion of "subject" as "first substance," hypokeimenon, an underlying thing or essential unchanging essence, which persists when other aspects change. The question of the metamorphosis of the actress in "Crisis" does set up such a dilemma. How is it possible for a person to have undergone 
metamorphosis - that is, a total substitution rather than evolution-and yet appear from the outside to be unchanged? How do we know that a metamorphosis has occurred?

The two occasions when the actress plays Juliet, once at 16 and again at 30, may indicate stages in a metamorphosis: the first being "youth" and the second "maturity." Yet "youth" and "maturity" are characteristics of an individual who appears to be the same in both stages. Juliet, says Kierkegaard, is the most significant assignment for any actress; "no 16-year-old could play her." Yet this sixteen year-old did play her. What she did at sixteen, says Kierkegaard, was not only to relate herself to the author's words as any actress could, but relate "herself to herself" ("Crisis" 306). There was already in her an "essential genius" which related itself to what he calls "the idea of "feminine youthfulness"” ("Crisis" 306). In the straightforward sense of being a young girl of sixteen, "feminine youthfulness," is a "simple youthfulness" which time will destroy. If, however, there exists an ability to relate to the idea of "feminine youthfulness" then this is something that time cannot destroy. Here, the passing of time introduces the possibility of a dialectical relation to the idea of youthfulness. What time makes manifest is "the dialectical in her in the metamorphosis." "Simple youthfulness" is only one life and as such is inherently undialectical. It is the additional life, provided by the relation to the idea, which introduces the dialectic. The dialectic in turn makes "the genius more and more manifest" ("Crisis" 311-12 and 319). In The Concept of Anxiety, Kierkegaard ties the notion of "genius" to that of subjectivity. ${ }^{10}$ Through the actress, genius becomes manifest—not through the subjectivity of the actress alone but that of the actress via the role of Juliet.

For Kierkegaard, it is as though the actress at 30 becomes contemporaneous with her 16 year-old self: 
She will not long for the blazing of what has vanished... [P]ure, calmed and rejuvenating recollecting, like an idealized light will trans-illuminate the whole performance, which in this illumination will be completely transparent. ("Crisis" 323)

This lack of nostalgia, the regard which is not backward looking but which brings something forward from the past, what Kierkegaard calls "rejuvenating recollecting," is not a return, but a renewal and an intensification of the initial state, without moving backwards or forwards in any quantitative alteration. She will not be "young again" in a superficial sense but "only in the sense of ideality, will she be young and younger" ("Crisis" 319). Kierkegaard's characterization of the actress on the whole provides an unusually sympathetic and attentive portrait of a woman character in his work and his emphasis on the age and appearance of the actress and the "idea" of the feminine may invite an analysis of the role that gender plays in the "crisis" in question. For the moment, however, I will suggest that although ideality refers to an aesthetic category, it is the relation of the aesthetic to the religious that is of concern here. ${ }^{11}$

Kierkegaard's diary entries detail the agonising deliberations over the publication of "Crisis." Once it had been published though, Kierkegaard is clear. He says that the article might entice those "who live aesthetically" and who have given up reading him (because "I do not write anything but sermon books") to read him again and find something for themselves there. They will see that he has not become a religious author. He was that already, he says, when he wrote Either/Or and concurrently published two "upbuilding discourses." At the same time, the publication of "Crisis" confirms for him once and for all (once again) that the future use of indirect communication would be "indefensible." He no longer had to hide behind ambiguity or riddles. The publication of the article meant that any "illusion that I happened to get older and for 
that reason became a decisively religious author has been made impossible" (from journal entries published in Christian Discourses 419-423).

The significance of these deliberations for Kierkegaard seems to be that the religious was already there in the aesthetic but at the same time could not be realised without it. The aesthetic imagination enables us to sense infinite possibility not only for selfish or superficial motives but for the sake of a higher ideal. It is the dialectical relation to the aesthetic "ideality" of feminine youthfulness that engages the actress and it is through relating herself to such ideality, through the movement of what Kierkegaard calls repetition, that the actress is able to undergo her metamorphosis - allowing her to reveal that what appeared to be new was already present at the beginning. For Kierkegaard repetition does not occur in "ideality" as such. Ideality is whatever is expressed in language. It is representation and, no matter how eloquent, can never be the actuality that it attempts to describe.

If something, apparently the same thing, recurs at different moments of time, then it is easy to assume that repetition is taking place. Of course, the fact that it appears more than once is sufficient to say that it is not the same; those instances are differentiated through time as the first, second, third and so on. It is natural to assume that in repetition there would be an occasion or action that can be thought of as "the first," and as such is without precedent. The second time would, by conventional logic, rely on the first to inform it. In Kierkegaard's terms, however, a repetition is not "the second" (or third or fourth) in the usual sense. Instead it is a return to the first state. Such a return retains the originality of the first, indeed it is as if for the first time, not as a simple reduplication but as a "more intensive return to the beginning" ("Crisis" 324). This is what constitutes change as qualitative rather than quantitative. It is like a revolution in perspective, a radical break not constituted by a progression, the passage of time, amassing of 
knowledge and so on, but rather like the movement which Sartre calls "a folding back," a movement which, he says, determines subjectivity for Kierkegaard:

[K]nowledge cannot register this obscure and inflexible movement by which scattered determinations are elevated to the status of being and are gathered together into a tension which congers on them ... a synthetic meaning; subjectivity is temporalization itself; it is what happens to me, what cannot be but happening. It is myself in so far as I can only be born to adventure... . (cited in Wood, "Thinking God" 60)

A repetition then, in Kierkegaard's terms, cannot rely on the first to inform it. It must always be as though for the first time. The actual first time is a coming into existence of something that did not exist before. It is the "beginning" and as such is of concern to Kierkegaard specifically in Philosophical Fragments (along with Concluding Unscientific Postscript to Philosophical Fragments). In these texts, he questions how history can inform us on doctrines of Christianity that are underpinned by such paradoxical notions as the incarnation or the resurrection. He sets out to propose that knowledge must be discovered not only theoretically but practically, in life as it is lived subjectively.

In a section called Pars Secunda, Johannes Climacus tries to think propros auspiciis (on his own behalf) about what it means to doubt. If doubt did not exist as a possibility within human consciousness already, then there would be no way of evoking it. Is it then possible to put doubt completely outside of consciousness? Consciousness, however, is always in relation to something that it is not. Consciousness of truth, for example, is always in relation to untruth. Both truth and untruth can only exist through reflection as duality. Consciousness is not reflection but the relating factor in what Johannes calls a triad of consciousness. Reflection is the possibility of a relation and as such is dichotomous. Consciousness $i s$ the relation and as such is trichotomous in nature: "immediacy is reality; language is ideality; consciousness is 
contradiction. The moment I make a statement about reality, contradiction is present, so what I say is ideality" (Fragments 168).

How then, asks Johannes, does consciousness discover the contradiction? The question of recollection once more is raised: How can consciousness discover something that it does not already know? Johannes proposes that the idea of recollection must also be a contradiction; it is neither ideality nor reality, but ideality and reality that have been. This, he says, is a double contradiction since neither ideality nor reality can "have been;" they are not in the past, over and finished with. Consciousness emerges through the collision of ideality and reality and such a collision is repetition not recollection: "As soon as the question of a repetition arises, the collision is present." Just as ideality cannot be repeated, neither can reality:

When ideality and reality touch each other, then the repetition occurs ... That the external is, that I see, but in the same instant I bring it into relation with something that also is, something that is the same and that also will explain that the other is the same. Here is the redoubling [Fordobling]; here is a matter of repetition. Ideality and reality collide—in what medium? In time? That is indeed an impossibility. In eternity? That is indeed an impossibility. In what, then? In consciousness - there is the contradiction. (Repetition 275)

So repetition is this collision of ideality and reality that Johannes talks about. The challenge is for the actress to play Juliet, as though for the first time, at 30 years of age. The metamorphosis of the actress, then, seems to consist in revealing something that existed from the beginning but which is "not decisively used and does not decisively make its appearance before some time has passedprecisely this is the metamorphosis" ("Crisis" 319 ).

\section{IV.}

"At 30 the metamorphosis is successful," says Kierkegaard. By then the actress can give a "performance in the eminent sense" ("Crisis" 306). As she gets older, an actress can perfect her 
craft and take on roles in accordance with her age. This, says Kierkegaard, is "perfectibility" and there is nothing wrong with that. However, what is of concern in "Crisis" is not "perfectibility" but "potentiation," which is precisely that "more intensive return to the beginning" ("Crisis" 324).

The notion of potentiality, from Aristotle, means that beings can potentially act or be acted upon. The eyes, for example, have the innate potential for sight and whatever is seen is something which "acts upon" sight. Therefore, the potentiality of sight is to "be acted upon" (De Anima 170). Being able to draw is something that can be learned through practice and so the ability to draw is the potentiality to act. Actuality is the aim (telos), the end of potentiality. As such, actuality itself is the ultimate fulfillment of the potential of any act (or acting upon). For Aristotle, if potentiality had the ability not to pass over into the actual, then it also had to be impotentiality. Giorgio Agamben reworks the problem of potentiality posed by Aristotle in a way that might be helpful to touch on here, if only briefly. Aristotle states, "What is potential can both be and not be. For the same is potential as much with respect to being as to not being". (Homo Sacer 45$)^{12}$ Potential can pass over into actuality only at the point at which it sets aside its own potential not to be. For Agamben, this does not simply mean that "what is not impossible is possible," but that potentiality may, in setting aside rather than destroying im-potentiality, enable it to retain its full potential (not to be) (Homo Sacer 46). Strangely, it could be said that impotentiality, which belongs to potential itself, far from being im-potence or powerless-ness is in fact a kind of power: the power of a being to withhold from actualization.

This may make some sense of what Kierkegaard refers to as "the metamorphosis of potentiation" as "a more and more intensive return to the beginning", something which is closer to im-potentiality as it involves a decisive movement which retains its own potentiality rather 
than bringing about its abolition through actualization. ${ }^{13}$ The metamorphosis of the actress then, in part, seems to consist in that return to the beginning which becomes re-charged with an ever more concentrated im-potentiality, in which subjectivity maintains itself in a state of anticipatory becoming, something which was present from the beginning and which is continually re-instated from the beginning.

At 16, the actress already had what Kierkegaard calls an "indefinable possession;" a quality of extreme rarity. At 30 she still had it. Kierkegaard does not absurdly try to define the "indefinable," but nonetheless presents some pointers by degrees of approximation. Something like a transforming activity seems to take place. Within or through the actress, energy and exuberance are transformed into an external calm which draws the audience into the performance. The actress, he says, is "in proper rapport with the onstage tension." Onstage tension here is the "weight of all those eyes," the public who are waiting expectantly and who sit in judgement ("Crisis" 312). At 16, the young actress is "in her element in the tension of the stage; precisely there she is light as a bird." Onstage what is made manifest is not tension but lightness. One becomes light by means of weight says, Kierkegaard ("Crisis" 312). Over the years, the actress had gained acclaim and recognition for both her art and her social standing. In that time, says Kierkegaard, it has become a "national duty" to admire her. ${ }^{14}$

The first time, the actress could rely on the gravity of the world to support her and to lift her into flight. The second time, "the weight of all those eyes" was not on her. Her performance became more difficult, not because the audience had high expectations, but precisely the opposite. The crowd's admiration could not be sustained through years of familiarity; habit means getting used to even the most extraordinary things and consequently always wanting something new. Kierkegaard talks about people in the public eye making rare appearances, or 
taking a long time to write novels in order to give an illusion of rarity and worth. This actress, however, appeared often to the crowds in Copenhagen and her availability was in danger of undermining their admiration. Kierkegaard paints an image of the crowd not like a blood-thirsty mob, wishing her downfall, but rather as a weary and well-meaning lot who feel sympathetic to her getting older but also feel slightly awkward that their enthusiasm for her is simultaneously waning:

People do wish her well ... they are really angry with time, that it will make her older now when they have cosily settled down into the admiration's habit of thinking that she should always remain eighteen years old ... and no-one considers that this whole thing may be balderdash that is totally out of place, at least in esthetics, since her era will really begin with the metamorphosis. ("Crisis" 318)

The habit of the crowd towards the actress changes nothing of her qualities, says Kierkegaard, but it makes her metamorphosis more difficult. The "onstage tension" is less than it had been at the beginning. Nonetheless, the actress willingly subjected herself to their tepid admiration. This very difficulty is what made the metamorphosis possible ("Crisis" 315). The second time, the actress could not rely on the crowd to create the "onstage tension" on which her performance relied. Instead, she had to create it herself. She did this through that inward movement, passion. At the point where she was the least supported by the crowd, when they least believed that she could still play Juliet and where she found herself entirely alone, only then could she surpass herself.

The figure who took it upon herself to both produce and to bear the weight of the onstage tension, in order to effect the metamorphosis, was neither the actress herself nor the character of Juliet. She was neither 16 nor 30 . She is all of these and at the same time none of them. In the same way, it is difficult to say precisely where or when the transformation took place. It is as 
though the decisive moment of the metamorphosis, its inception, was already present in the actress at 16 . Once again at 30, another decisive moment precipitates the transformation. The actress via the role of Juliet made the metamorphosis by virtue of a decision which seemed to "take place" not at one definable point but rather in that strange temporality or movement called "the moment." 15 What the actress performed, then, was what Kierkegaard calls repetition. Repetition cannot rely on the first instance to inform it. It must always be as though for the first time. The actual first time is a coming into existence of something that did not exist before. Repetition is like that momentary passion in which I leap out of existence. In order to make this move, it is necessary to "press forward" without seeking reassurance from the past and yet at the same time to undergo a more intensive return to the beginning ("Crisis" 317).

"A woman does not become an actress in her $18^{\text {th }}$ year, if she becomes that at all it's in her $30^{\text {th }}$ year," says Kierkegaard ("Crisis" 306). The second time for the actress provided an opportunity for the culmination of the "serving relation to the idea" of youthfulness. A 16-yearold, says Kierkegaard, is "too confident," "coy" or too concerned with what is happening on the outside to be able to undertake such a serving relation. The actress was not concerned with externals, but performed her role with complete inwardness. Her metamorphosis was not only a return to the first state, but a transformation of herself "in an eminent hypostasis" ("Crisis" 322323). What came about in that metamorphosis was a "rejuvenating recollecting," and as such was not a retrogressive movement but one which re-invested that beginning with more potential than before. She could not look for consolation in the past. At the same time, despite the passage of time, in her metamorphosis she re-inhabited her younger self with a renewed perspective. 
V.

It is easy to imagine the trepidation of the 30-year-old actress in her dressing room as she prepares to go on stage. There is nothing unusual about pre-performance nerves. This however, was not going to be just any performance but, to repeat Kierkegaard's words, "a performance in the eminent sense" which will make the "genius" manifest. For such genius, anxiety is different from the ordinary anxiety of life. It may feel the same, but its relation to "danger" is the inverse.

The "weight of all those eyes" was not on her. Indeed not much was at stake for the audience even if everything was on the line for her; it would be the performance which made an actress of her. The actress, says Kierkegaard, is anxious in the wings or "back home in her study" where she has "no weight upon her," but onstage "there is not a trace of anxiety..." ("Crisis" 312-313). Ordinary "men," he says, feel secure until the moment of danger. Then they are anxious. As soon as the danger has passed, anxiety disappears. Genius, by contrast, becomes anxious before and after the moment of danger but the moment itself makes the genius strong:

[Her] anxiety ... lies in the moment before and after the danger, that trembling moment when [she] must converse with the great unknown, which is fate. [Her] anxiety is perhaps greatest precisely in the moment after, because the impatience of certitude always increases in inverse ratio to the brevity of the distance to victory, since there is more and more to lose the nearer one comes to victory, and most of all in the moment of victory, because the consistency of fate is precisely its inconsistency. (Anxiety 101)

Because the crowd was nonchalant, because there was no expectation from them to be enchanted, delighted or surprised by her performance, the danger was greater. She was no longer like the Court Chaplain in Berlin who, by giving a sermon only once in a while, could guarantee a hoard of people stampeding each other to get a seat in the audience ("Crisis" 317).

Anxiety, for Kierkegaard, is not just pre-sentiment: "all existence...from the smallest fly to the mysteries of the Incarnation makes me anxious" (Anxiety xii - xiii). I am born into it and it 
is part of me. It is "a threat to the foundation and centre of one's existence" and at the same time, for Kierkegaard, a privileged emotional state which can encourage transformation of the highest kind (Anxiety xvii). In anxiety, I am confronted with the "dizziness of freedom" in the face of infinite possibility; I see all of existence as possibility, its joys as well as its horrors. An individual in freedom is free to decide but, in deciding, carries out its own execution. By cutting off its own infinite possibility, it becomes limited and finite. The idea that possibility is light is often heard, says Kierkegaard, but possibility is the weightiest of all categories.

The actress could have performed any role, one more aligned to her age and status and which showed how she had perfected her craft. However, she chose to play Juliet; a role that, more than any other, could more readily confirm the public's expectation that she was past her best. She undertook the task, subjected herself to the ordeal and, in doing so, created the necessary "weight," the anxiety, that precipitated her metamorphosis.

In undergoing such anxiety, assuming the weight of possibility, the actress surrendered to existence in order to be transformed:

In actuality, no one ever sank so deep that he could not sink deeper, and there may be one or many who sank deeper. But he who sank in all possibility—his eyes became dizzy, his eyes became confused, so he could not grasp the measuring stick that Tom, Dick, and Harry hold out as a saving straw to one sinking ... He sank absolutely, but then in turn he emerged from the depth of the abyss lighter than all the troublesome and terrible things in life ... I will not deny that whosoever is educated in possibility is exposed to danger ... [but] the assaults of anxiety, even though they be terrifying will not be such that he flees from them. The Anxiety enters into his soul and searches out everything and anxiously torments everything finite and petty out of him, and then it leads him where he wants to go. (Anxiety 158)

We can think of "anxiety" like a lock on a canal, which it is necessary to go through in order to take a boat to another level and to continue on an otherwise inaccessible route. Anxiety 
is not only this mechanism but provides the force or the momentum with which to turn it. In reality, though, nothing could be detected as a medium of change in the metamorphosis of the actress. No one could say from the outside if she really had passed through it and if indeed she was set on a new path once and for all. What can be said is that in the moment of danger onstage, the actress did not give a backward glance to already-rehearsed certainties. She played the role of Juliet at the age of 30 as though for the very first time. No director could have instructed her. She arrived, through her own efforts at that more intensive return to the beginning.

\section{VI.}

By now it is clear that the performance of the actress as Juliet aged 30 is a feat worthy of attention. Even so, the word "danger" seems to be an exaggeration here. Given that this is a mere theatre performance, how can such a thing really be considered dangerous? It remains difficult to assign this performance with the same sense of urgency that Kierkegaard invokes through his rendition of Abraham's trial, for instance. Are we any closer to understanding what really is at stake for Kierkegaard in the publication of "Crisis"?

The title of the article includes the word "crisis" twice, and yet nowhere in the article itself is a crisis, as such, referred to directly. The precise nature of these two crises and their relationship to each other is still unclear. The first "crisis" of the title "The Crisis" suggests a crisis in general. As previously mentioned, Kierkegaard felt that the political, religious and philosophical ideas taking root in Denmark around 1847-8 were profoundly antithetical to his thinking. There was a great deal of instability and change in Denmark. As well as this, German philosophy, in particular Hegelianism, was beginning to dominate the intellectual landscape in Europe and subsequently in Denmark itself. Hegel's spectacular intelligence and profundity as a 
philosopher was not in doubt for Kierkegaard but he believed that Hegel was trying to systematize existence and in doing so was attempting to stand outside of the system he himself had created, thus assuming an authority and objectivity that no human being can claim. Kierkegaard feared for the fate of Danish philosophy which he said, was different from German philosophy. It did not seek explanation in the way that German philosophy did but instead began with "the proposition that there are many things between heaven and earth which no philosophy has explained" (Papers 181).

The second crisis of the article's title is a crisis in particular, "a crisis in the life of an actress." Why does Kierkegaard call the situation of the actress a "crisis" and not "metamorphosis" since the latter is what is ostensibly of concern in the article? The term crisis comes from a medical source, indicating the very worse point of an illness where the patient either turns toward recovery or death. The word stems from the Greek krisis meaning "decision" (from krinein, to decide, separate, judge). The Latin decidere "to decide," means to cut off ( de + caedere, "off" + "to cut") as well as "to determine" or an act of volition. Etymologically, then, the words "crisis" and "decision" both come to mean the same thing: a turning point, or a point of renewal which is also a severance. Crisis does not precede decision but rather crisis is decision itself. Crisis as decision is the cutting off or the rupture with continuity, with the accumulation of past knowledge and experience. Such an act requires agency, subjective or otherwise. ${ }^{16}$

Kierkegaard's decision to publish the article, as I mentioned previously, was also a crisis of sorts. It was not the first time that the decision to publish had thrown him into a quandary. The case of "Crisis," however, illustrates quite clearly what rests on such a decision. ${ }^{17}$ This event of publishing itself seems to embody his concern in the discussion of the metamorphosis of the actress. The metamorphosis of the actress was complete at 30; this was not an end but rather the 
starting point, where she could actually begin to be an actress. At what point then does Kierkegaard begin to be religious, to become a Christian?

In "Crisis," Kierkegaard mentions the example of a young man. "When will he produce his best lyrical poetry?" he asks:

[I]n his twentieth year? By no means. His best lyrics will come at a somewhat older age, when time has taken away the fortunate accidentals of his youthfulness so that he now relates himself to his idea purely ideally and thereby, serving, also relates himself in a profound sense to his idea. ("Crisis" 320)

It is hard to avoid the conclusion that the "young man" in question here is Kierkegaard himself, replicating statements about the actress. Yet the "serving" in question is not only to an aesthetic ideal. Publishing "Crisis" meant that Kierkegaard was facing the prospect of sacrificing public recognition and respect as a literary persona in the cultural scene of Copenhagen. A religious author had much less appeal than an aesthetic one. ${ }^{18}$ However, there was, for him, something more profound at stake; what he says in relation to the "young man," calls to mind a matter that, for him, may have unthinkable consequences.

In journal entries around the time of publishing "Crisis," Kierkegaard wrote that he was continually haunted by the thought that he would soon die and that "Crisis" may be published after his death. In 1848 , Kierkegaard would reach his $33^{\text {rd }}$ birthday, the age when his father had predicted all of his children would die. ${ }^{19}$ Kierkegaard feared that if he reneged on his resolve to "speak" in direct communication, then God may abandon him. He believed that publishing this aesthetic "little article" actually placed him in spiritual danger. However, he also wanted to dispel any idea that the attacks he had suffered through "The Corsair Affair" had made him "saintly" and turned him towards Christianity, insisting that he had always been religious from 
the beginning and opposing the idea that religion was something a person turned to only in adversity or old age (Journals 319).

"Crisis" was not only an occasion to talk about his admiration for the actress and to reflect upon his own dilemma of becoming a uniquely religious author and a Christian "before God." It may also have provided the means by which Kierkegaard, in practice, could test his own (inward) commitment to serve God for himself. When Kierkegaard did publish the article, he commented in his journals that he was glad because if he had died without doing so he was certain "that in the frightful and frivolous conceptual confusion of our age people would have come out and babbled something about [him] being an apostle..." (Papers 322). However, in a sense his fears over public opinion were, from the outside at least, inflated beyond any reality. His real anxiety seemed to lie in whether he was following God's will or not, whether in publishing the article he was in fact serving an aesthetic rather than a religious motive.

In an essay called "Difference between an apostle and a genius," also written in 1847 (and published in 1849), Kierkegaard states that the genius, if he were an artist, would produce works of art without telos. The genius is a lyrical author who writes without an "in order to." His work is a sort of self-development. The apostle, however, has a "sacrificial life;" although he is poor, says Kierkegaard, "he makes others rich" (Authority 179-180). The apostle serves an ideal beyond himself and he is called by God to do so. The work of an apostle and a genius might even look the same—but it would be doing a different job—only God knows who is an apostle and who is not, and only God designates and calls upon the apostle to do his work. The question of how one knows if one has been called by God or whether one is a victim of one's own delusions is one that haunted Kierkegaard. This and the derision he showed at the thought of being called an "apostle" after his death echoes another crisis in his life four years earlier: "The Adler affair." 
Adolph Peter Adler was pastor in the Danish island of Bornholm who became a Magister of Theology and, like many at the time, a great follower of Hegel. In 1842, he claimed to have had a revelation from Christ which turned him against Hegel and commanded him to burn all of his previous writings. He was informed that he would be dictated a new work in revelation. In 1843 (the year that Fear and Trembling was published) he published four books simultaneously of sacred verses and insights that he claimed were from Jesus. Kierkegaard, who knew Adler, bought the books and subsequently wrote The Book on Adler, a scathing critique of Adler. Despite his scepticism, there remained for Kierkegaard the possibility that Adler had in fact received direct communication from Christ. Even if he felt that the manner in which Adler expressed himself was undignified or that he was potentially prone to hallucinations or delusions, his claim was immune to all criticism; it was indefensible, but as Kierkegaard himself admitted, at the same time inviolable. How could he know for sure that Adler was not speaking the truth?

The situation that Kierkegaard was trying to come to terms with in the writing of Fear and Trembling through the figure of Abraham, came to life in the form of Adler. However, Adler became an object of both envy and fear for Kierkegaard; the man was either a madman or an apostle of Christ and nothing in Kierkegaard's powers could discover the truth. By claiming that he had a revelation from God and that he had been chosen to deliver this revelation to humanity, Adler was announcing that he was an apostle, something that would have seemed outrageous to Kierkegaard. It is easy to imagine his frustration. An apostle (from the Greek apostolos, meaning one who is sent, i.e. by God) would never make such a boastful claim. On the contrary, argues Kierkegaard, "the authenticating mark of the apostolic is an existential humility of the most radical kind" (Adler xx). However, by speaking out in such a way, Adler could also be the mocked and ridiculed outsider, who is also the true apostle. 
The fact that Adler later claimed he was a genius, not an apostle did not resolve the matter. A genius, says Kierkegaard, is born (Genius from the Latin ingenium, means inborn talent or ability). The apostle is not born but sent by God on a mission:

A genius and an apostle are qualitatively distinct, they are categories which belong each of them to their own qualitative spheres: that of immanence and that of transcendence ... The genius is what he is by reason of himself, i.e. by what he is in himself: an apostle is what he is by reason of his divine authority. (Adler 201)

Either claim was problematic for Kierkegaard. If Adler really was the recipient of a revelation then how could he turn round and claim it as his own work of genius? Whatever the truth of the case of Adler, what remained for Kierkegaard was the impossibility of ever knowing for sure what took place. At the interior of ourselves, the place at which the unknown summons us is always sealed off, untransmissable, unpresentable and unjustifiable. For Steiner, "[t]he crux of the Adler affair is that of 'calling,' in the very strongest sense of the term" (Adler xix).

Whilst there is a temptation to overload this "little article" with significance, to entice it to reveal an interpretative schema which may fit neatly into Kierkegaard scholarship, this would perhaps be precisely what Kierkegaard himself would warn us against. Although it is clear that Kierkegaard's motifs of repetition, anxiety, genius and potentiation are brought to bear once again in "Crisis," the article seems to signal the difficulties and indeed the undesirability of existential "categories."

When "Crisis" finally appeared in Fadrelande on July 1848, it passed without remark. Perhaps the fact that, like the actress, "the weight of all those eyes" was not on him provided the very momentum which made Kierkegaard's transition to Christian authorship possible and his own internal metamorphosis. However the publication of the article signals that at no time can I say definitively "now I have achieved religiousness." I may well find myself immersed in the 
aesthetic once more. Kierkegaard warns us here that progression through the stages of the aesthetic, ethical and religious, from one to the next is neither guaranteed nor final. Such cherished categories become undone in the moment of crisis.

Sartre said that Kierkegaard taught him what was entailed in calling oneself an atheist. Kierkegaard does this, says Sartre, by tracing through his writing the passage back "from speech to speaker." Such "verbal alliances," he says, are "not intelligible":

When we encounter his words, they immediately invite us to another use of language, that is to say of our own words ... Kierkegaard's terms refer us to what are now called, in accordance with his precepts, the "categories" of existence ... Within each of us he offers and refuses himself, as he did in his own lifetime; he is my adventure and remains, for others, Kierkegaard, the other-a figure on the horizon testifying to the Christian that faith is a future development forever imperiled, testifying to myself that the process of becoming-an-atheist is a long and difficult enterprise. (Between 168)

The character of Juliet via the actress, the performance of which is authored by Inter et Inter alias Kierkegaard, produces such a chain of "unintelligible alliances." The trajectory takes us back to Kierkegaard but also to ourselves. Who is this actress if she is not every single individual, both the unknown reader and Kierkegaard himself?

"The Crisis and a Crisis in the Life of an Actress," like Fear and Trembling, expresses what is at stake in assuming the responsibility of freedom as an existing human being. To become an actress, to become subject, to become a Christian, atheist, a philosopher and so on, requires a radically subjective move which propels me towards the moment of crisis and which at the same time returns me to the beginning. The hope is, for Kierkegaard, that when "the tug of decision" occurs, we can respond with a passion "that changes everything." 


\begin{abstract}
Notes
${ }^{1}$ Several journal entries around the time of publication use this term. See Journals 319-322. From here on "The Crisis and a Crisis in the Life of an Actress" will be referred to as "Crisis."

${ }^{2}$ Frau Heiberg also happened to be married to J. L. Heiberg, a prominent figure in literary circles of Copenhagen and chiefly responsible for bringing Hegelianism into Denmark. Kierkegaard was keen on making an impression on her husband and spent a lot of time and energy trying to get into his circle but eventually gave up when he found his "own voice." For letters addressing
\end{abstract} Herre Heiberg, see Fear and Trembling and Repetition.

${ }^{3}$ For more discussion on this see Ricouer, "Philosophy after Kierkegaard."

${ }^{4}$ We are reminded here of the secret maintained in Abraham's response when Isaac asks the whereabouts of the sacrificial animal: "God will provide," he says. This is, according to Derrida, a way of speaking without speaking (Gift 72).

${ }^{5}$ Here he also says that Fear and Trembling, Repetition and Either/Or are all commentaries on the category of "the single individual."

${ }^{6}$ Paradox is one of Kierkegaard's key terms, especially in relation to Christian faith, which for Kierkegaard is not a matter of learning dogma, but rather a subjective relationship to the unknown "God," a relationship which has to be continually renewed in faith.

${ }^{7}$ In the $19^{\text {th }}$ Century, psychology was part of philosophy, and although Kierkegaard would have been aware of developments in the area of psychology, in using the term "psychological" he would have had in mind something quite different than a scholarly idea. Howard and Edna Hong suggest that: "'Psychology' and 'psychological' qualify the imaginative constructing by adding an emphasis on the embodiment of a view or views of man in characters, events, relations, just as the poet makes the imaginative construction in palpable form, the idea made visible, a philosophy of man in concreto" (Fear and Trembling xxix). Elsewhere, Kierkegaard says that "being is the abstract prototype" of what is in concreto (Postscript 190).

${ }^{8}$ The term pseudonym usually means assuming a name of one who is not known. Just as many writers say that their novels were dictated to them by a voice, or that a character in their work seemed to have a will of their own, so too might have Kierkegaard's pseudonyms come about.

${ }^{9}$ Inter et Inter is also reminiscent of aut/aut, the Latin translation of either/or, as Howard and Edna Hong point out (Christian Discourses xvi).

${ }^{10}$ After Hegel as the "particular nature of a man who decides his actions and destiny" (Anxiety 98 ftn.).

${ }^{11}$ I am not able to do justice to this important discussion here. I will acknowledge this as an omission and hope to enjoy another author's interpretation of the issue. For the moment, I would 
like to note that authors such as Dera Sipe (in "Kierkegaard and Feminism: A Paradoxical Friendship") suggests that Kierkegaard's critique of Western philosophy and his literary strategies created a space in which to develop a model of thinking other than the dominant universal, objective, normative paradigm. She suggests that Kierkegaard may be useful to feminist theory. Even if his first published work, a short essay entitled "Another Defense of Woman's Great Abilities," published at age 21, appears to be vociferous in its misogyny, Sipe points out that we have to remember that it was written under the pseudonym A (also the 'author' of Either/Or and ostensibly referring to the young man in Repetition). This might make the alignment of views expressed by the authorial voice of Kierkegaard more problematic.

12 Aristotle cited in Agamben (Homo Sacer 43-45).

${ }^{13}$ Here and in subsequent texts, Agamben examines the consequences of Aristotle's formulation for the paradigm of sovereign power through Foucault and others. There is an interesting discussion to be had in relation to Kierkegaard here but I feel that I cannot do it justice in the space of this essay.

14 "She has become the "nation's daughter"” ("Crisis" 313).

15 The category of the moment is central to Kierkegaard's thinking (the "instant," says Derrida, is always indispensable in Kierkegaard [Gift 72]).

16 And yet, says Derrida: "One never meets decision or experiences it - it is something which interrupts and tears the fabric of time" (On Responsibility 20).

${ }^{17}$ In Walter Lowrie's Introduction to Training in Christianity, he explains that the decision to publish that text was also fraught with "the agony of indecision." Kierkegaard was so troubled by the news that Regine Olsen's father had died that he suffered auditory hallucinations, which, in the end, prompted him to publish. Lowrie remarks that Kierkegaard would have been sufficiently aware that those "voices" were part of him but they were nonetheless so terrifying for him that he felt compelled to do as they said (Training in Christianity p1.1).

18 As Walter Lowrie comments in his introduction to Training in Christianity, "to decide for Christ' was also to become a 'cultural alien"' (xvii).

${ }^{19}$ At the age of twenty-four, Kierkegaard's father revealed to him that once, as a starving shepherd boy on a Jutland heath, he had cursed God for his miserable situation. Although his fortunes quickly turned around, his father was haunted by the belief that all of his children would die by the age of 33, the age at which Christ died on the cross. Of his seven children only Peter and Søren survived beyond that age. 


\section{Works Cited}

Agamben, Giorgio. Homo Sacer: Sovereign Power and Bare Life. Translated by Daniel HellerRoazen. Stanford, CA: Stanford University Press, 1998.

Aristotle. De Amina (On The Soul). Translated by Hugh Lawson-Tancred. London: Penguin, 1986.

Derrida, Jacques. The Gift of Death. Translated by David Wills. Chicago: University of Chicago Press, 1995.

—. "On Responsibility; an interview with Jonathan Dronsfield, Nick Midgley, Adrian Wilding." University of Warwick Journal, May (1993): 19-35

Kierkegaard, Søren. Christian Discourses and The Crisis and a Crisis in the Life of an Actress. Translated by Edna H. Hong and Howard V. Hong. Princeton, NJ: Princeton University Press, 1997.

- Fear and Trembling and Repetition. Translated by Edna H. Hong and Howard V. Hong. Princeton, NJ: Princeton University Press, 1983.

-. Kierkegaard, Søren. Fear and Trembling and The Book on Adler. Translated by Walter Lowrie, London: Everyman's Library, 1994.

—. Papers and Journals: A Selection. Translated by Alastair Hannay. London: Penguin Books, 1996.

-. Concluding Unscientific Postscript to Philosophical Fragments. Translated by Edna H. Hong and Howard V. Hong. Princeton, NJ: Princeton University Press, 1974.

-. Philosophical Fragments and Johannes Climacus. Translated by Edna H. Hong and Howard V. Hong. Princeton, NJ: Princeton University Press, 1985.

—. Training in Christianity. Translated by Walter Lowrie, New York: Vintage Books, 2004.

- The Concept of Anxiety. Translated by Reidar Thomte and Albert B. Anderson. New Jersey: Princeton University Press, 1981.

- Without Authority, Translated by Edna H. Hong and Howard V. Hong. Princeton, NJ: Princeton University Press, 2000.

Ricouer, Paul. "Philosophy after Kierkegaard." Translated by Jonathan Rée. Kierkegaard: A Critical Reader. J. Rée and J. Chamberlain (Eds). Oxford, UK: Blackwell, 1998. 9-25 
Sartre, Jean-Paul. Between Existentialism and Marxism. Translated by John Mathews. London: New Left Books, 1974.

Sipe, Dera. "Kierkegaard and Feminism: A Paradoxical Friendship" http://evans-experientialism.freewebspace.com/sipe.htm [last accessed 17 April 09]

Wood, David. "Thinking God in the Wake of Kierkegaard" in J. Rée and J. Chamberlain (Eds). Kierkegaard: A Critical Reader. Oxford: Blackwell, 1998. 53 - 74 